\title{
Learning Styles and Academic Achievement of Secondary Agriculture Students in Eldoret East Sub-County, Kenya
}

\author{
Muge Josephine Chepchumba \\ Egerton University, Department of Agricultural Education, Faculty of Education and Community Studies, P.O. BOX 536, Egerton, \\ Kenya
}

\begin{abstract}
Learners process incoming information in different ways; hence, the instructors need to vary their methods of teaching to ensure that all students learn. This study investigated the learning preferences and their influence on the academic achievement of 291 form three agriculture students in Eldoret East Sub County. Purposive sampling was used to select 10 co-educational secondary schools from which 291 respondents were systematically selected into the sample by use of random numbers. Descriptive survey study design was adopted for the study. The Kolb's Model of experiential learning was the theoretical model for the study. The Kolb's Learning Style Inventory (KLSI) and an Agriculture assessment test (AAT) were used as research instruments to collect the data. KLSI was used to profile the learning styles of agriculture students as one of the four learning groups: Converging, Diverging, Assimilating and Accommodating. Statistical Package for Social Sciences computer package version 21 was used in the analysis of the data obtained using frequencies, percentages, means and standard deviations and Chi-square test. The hypothesis was tested at a 0.05 level of significance. The findings indicated that majority of the agriculture students were convergers followed by assimilators and thirdly by accommodators. The least preferred learning style was diverging which was preferred by 16 percent of the students. The study revealed that there was a statistically significant difference between learning styles and academic achievement of secondary school agriculture students. This study recommends that Agriculture teachers should identify the learning style of their students and use teaching strategies that complement them. The use of multiple teaching methods will greatly enhance the process of teaching and learning and make it effective and rewarding.
\end{abstract}

Keywords: Learning Styles, Secondary Agriculture Students, Achievement

\section{Introduction}

When you submit your paper print Agriculture is the mainstay of the Kenyan economy. It accounts for approximately 27 percent of Kenya's Gross Domestic Product (GDP) and the main source of livelihoods for about 80 percent of the population in rural areas (Ministry of Agriculture $[\mathrm{MoA}], 2014)$. Agriculture has also greatly factored as a source of income for small scale farmers and contributed to the country's economy as a foreign exchange earner Gor et al., 2012). The importance of agriculture to the economy may account for its inclusion in school curriculum as a subject for every child of school age to acquire the appropriate skills that will enable him cope with life challenges. However academic achievement of secondary school agriculture students has not been satisfactory. The students' mean scores in the subject from the year 2007 to 2013 were less than 50 percent of the expected score nationally. The mean scores in Agriculture in Eldoret East Sub County ranged between 5.11 and 5.62 out of the possible 12.00. This poor performance has been partially attributed to students' learning styles; their interest in the material under study, motivation and the learning environment. Few empirical studies have been done to determine the link between learning styles and learners' achievement in secondary school agriculture.

\subsection{Literature Review}

Students' learning styles make an important component in the learning environment. Learning Style refers to ways learners concentrate, process, internalize, and remember new and difficult academic information and skills (Shaughnessy, 1998). There are numerous learning style models and instruments used in assessing students' learning styles. Kolb, (1986) experiential learning model is one that is established and widely used by researchers (Claxton \& Murell, 1987). This model identifies four learning styles: converging, diverging, assimilating, and accommodating. Every student learns and responds to information uniquely (Chang, 2010). The learners' learning style is one factor researchers acclaim influence students' educational performance. Matthews, (1996) noted that learning style had a significant effect on the perceived academic achievement.

Studies on learning processes are formalized to understand individual differences. The starting point is that different people have different ways of learning which seem natural and preferable for them. This means that some types of learning experience suit them better than others. By a suitable, preferred learning type, the individual can learn lots of things, if not; all of the experience can turn to be a waste of time. The extension of the individual differences in cognitive style and learning preferences can be considered through the Experiential Learning Theory of Kolb (Honey, 1999; Hsu, 1999; Kolb, 1985).

\subsection{Learning Style and Achievement}

Research has shown that the relationship between learning style and academic achievements is linear (Chamorro, 2008). According to Ornestein, (1992), good performance is the 


\section{International Journal of Science and Research (IJSR) \\ ISSN (Online): 2319-7064}

Index Copernicus Value (2015): 78.96 | Impact Factor (2015): 6.391

ultimate goal of every learner. Research has established that learners with high performance-orientation to acquire knowledge are extrinsically motivated in terms of learning behaviors due to the reward which will come as a result of high performance, while learners who embrace superficial learning styles focus on the minimum effort necessary to ensure success (Marshall, 1999). Educators therefore should encourage learners to take a deep learning approach as opposed to memorizing information, rote learning and learning facts without a meaningful context. Knowledge about students' learning style can benefit students and teachers. For students it will help them understand their own strengths and weaknesses and consequently learn more effectively and take responsibility for their own learning (Honey and Mumford, 1992). For teachers it may help them consider appropriate teaching strategies that enhance students learning strength. Their awareness of students learning styles would help them in making informed choices in course material and learning process.

Effective learning requires matching materials to learner's abilities and learning styles (Honey \& Mumford, 1992). If these do not match, frustrations set in making learning more difficult. When the learning style of students in a class and the teaching style of their teacher are mismatched the students may become uncomfortable and inattentive in class. This possesses further challenges for educators in assisting students in learning and succeeding academically (Felder and Spurling, 2005).

\section{Method}

This study adopted a cross-sectional survey research design. A group of 291 form three agriculture school students in Eldoret East Sub County (248 male and 243 female), were randomly selected and participated in the study. They were asked to fill out Kolb's Learning Styles Inventory in order to determine their learning styles. Learners were also given the Agriculture Assessment (Test AAT) which was used to determine their academic achievement.

\subsection{Instruments}

Kolb's Learning Styles Inventory Perhaps one of the best known and most widely used questionnaires is the Learning Style Inventory (LSI) based on Kolb's learning styles. The LSI can be used purely for self-knowledge so individuals can understand and manage their learning preferences; and is also useful for facilitators/educators, so they can design learning events to appeal to all learning style preferences. The LSI enables people to identify which phases in the learning cycle they prefer and which they avoid. It also helps them to develop practical strategies for completing the full cycle in order to strengthen their overall learning abilities.

Each of us has a tendency to operate from a preferred phase. But we learn most effectively and completely when we work through a full cycle. The Learning Style Inventory is a statistically reliable and valid, 12 item assessment tool, developed by David A. Kolb. Based on Experiential Learning, learning styles are categorized as Diverging,
Assimilating, Converging, and Accommodating, Kolb (1986). An agriculture assessment test (AAT) adopted from KNEC past examination papers and modified was used to measure the students' achievement. It contained five sections covering the topics Crop production, Livestock production, Agricultural economics, farm tools and equipments, and farm power and machinery. 10 Structured questions with a maximum score of 20 marks in each of the five sections were provided. The performance scores of the students in these five areas were analyzed with respect to their learning styles. The Cronbach's coefficient alpha of 0.745 was obtained in the Kolb Learning Style inventory and 0.71 in the Agriculture Assessment Test implying that the research instruments were reliable and therefore the researcher adopted them

\subsection{Theoretical Framework}

The theoretical framework guiding this study is Kolb's theory of experiential learning (Kolb, 1984) and that by Lamm et al., (2011) describing the relationships between learning style and academic achievement? Based on the results of an exploratory study, Lamm et al., (2011) suggested that educators could plan curriculum to enhance deeper learning by considering the students' learning styles (Kolb, 1984; Kolb, 2007) and problem solving styles (Kirton, 2003). Kolb's Experiential learning theory (ELT) builds on this idea, grounded in the theory that all learning begins with an experience, which is then processed into knowledge. This theory of learning is congruent with the secondary agriculture syllabus which focuses on hands-on application, where student experience is given an essential role in the learning process. The agriculture syllabus in secondary school is designed to give students experiences that simulate tasks that are performed in the school farm which act as an agriculture laboratory. This model is relevant to this study in that the study of agriculture is based on Experiential learning as an integral element, (Roberts, 2012). The experiential learning model, when placed on the agricultural education model, illustrates the total learning experience of agricultural education, where the learner in the three cycle model sees, say something and the SAE portion allows students to take what they have seen in the classroom and apply it in real life agriculture experience. Learning style is defined by the experiential learning theory of development (Kolb, 1984) as an individual's preferred method of gaining knowledge. Kolb (1984) posited that styles of learners separate into four categories: accommodating, assimilating, converging, and diverging. The four styles were developed by assessing the level at which a learner naturally uses specific tendencies while learning. They include reflective observation (reflecting), abstract conceptualization (thinking), active experimentation (doing), and concrete experience (experiencing) (Kolb, 2007).

Typical characteristics associated with each of the four styles were also identified (Kolb, 2007). Individuals with a preference for doing and experiencing are considered accommodators. These individuals put practiced ideas into action, find multiple uses for information, and are easily adaptive. Individuals with a preference for reflection and thinking are considered assimilators. Assimilators look at 


\section{International Journal of Science and Research (IJSR) \\ ISSN (Online): 2319-7064}

Index Copernicus Value (2015): 78.96 | Impact Factor (2015): 6.391

learning as a gateway to larger ideas and prefer to combine learned information to create models and theories. Convergers prefer doing and thinking, collecting information to solve problems and prefer to reach a solution by bringing ideas together. Divergers prefer experiencing and reflecting. Divergers view situations from multiple perspectives looking for alternative solutions by diverging from traditional

\section{Results and Discussion}

All the participants completed Kolb learning style inventory. Using the results of the Learning Style Inventory, the distribution of the students according to the four learning styles was determined.

Table 1: Demographic Characteristics of the Respondents

\begin{tabular}{|c|c|c|c|}
\hline Differentiation & Groups & Frequency & percentage \\
\hline \multirow{3}{*}{ Gender } & Boy & 148 & 51. \\
\cline { 2 - 4 } & Girl & 143 & 49. \\
\hline \multirow{3}{*}{ Age } & 15 & 13 & 4 \\
\cline { 2 - 4 } & 16 & 116 & 40 \\
\cline { 2 - 4 } & 17 and above & 162 & 56 \\
\hline
\end{tabular}

From the information in Table 1, the findings indicated that 49 percent of the students who participated in this study were female while 51 percent were male; which meant that more boys chose agriculture than girls. That could have been due to commonly observed gender norms that push females into gender-stereotyped fields and away from math and science fields. Over half (56 percent) of the students were 17 and above years old. This was attributed to proof of age for admission to basic education institutions where by one is admitted on attainment of the school going age of four years

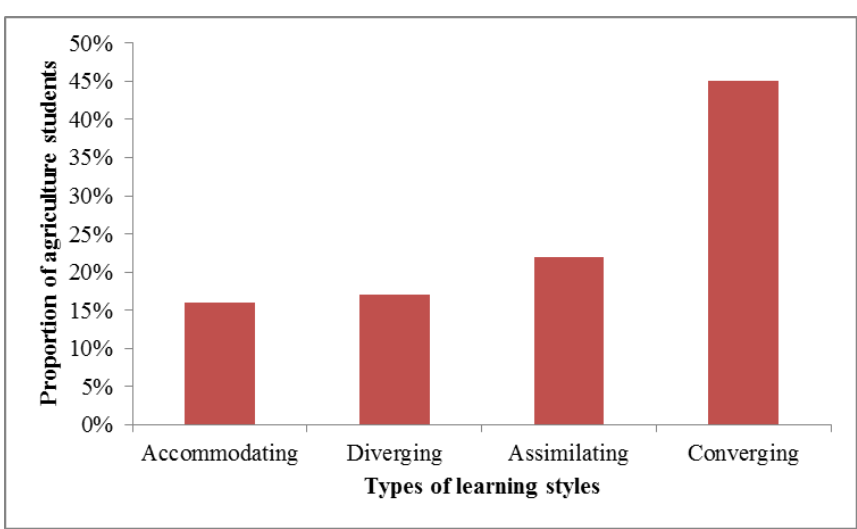

Figure 1: Types of agriculture students' learning styles

The agriculture students owned least the Accommodating learning style which was 15.8 percent. Majority of the respondents had the Converging learning style than any other learning style. This study also agrees with the findings by Adel and Louis, (2003). Adel and Louis investigated into the preferred learning styles of 274 accounting and Marketing students in the Clayton State University and their findings were that all the four learning styles existed. However preference of majority was Converging Learning style. The converger's dominant learning abilities are in abstract conceptualization (AC) and active experimentation (AE). The convergers' greatest strength is in the practical application of ideas (Kolb, 1985; 2009).

\subsection{Learning Styles and Gender}

Further analysis was done to establish the differences in learning styles of students who participated in this study based on gender. The findings were as presented in Table 8 . There were more male accommodators (8.2 percent), divergers $(8.6 \%)$, and convergers $(24.1 \%)$ than female $(7.6$ $\%, 8.2 \%$ and $21 \%$ respectively). There were more female students $(12.4 \%)$ who were assimilators than male $(10 \%)$ students. This implies that female and male students perceived learning styles differently. This compares well with Cezair, (2003) findings that female students extremely preferred assimilating learning style whereas male students were in favor of converging learning style. Both male and female student's least preferred Accommodating learning style.

Table 2: Cross Tabulation of Gender and Learning Styles

\begin{tabular}{|c|c|c|c|c|c|c|}
\hline \multirow[t]{2}{*}{ Gender } & & \multicolumn{4}{|c|}{ Learning Styles } & \multirow[t]{2}{*}{ Total } \\
\hline & & Accommodator & Diverger & Assimilator & Converger & \\
\hline \multirow[t]{4}{*}{ Male } & Frequency & 24 & 25 & 29 & 70 & 148 \\
\hline & $\%$ within Gender & $16.2 \%$ & $16.9 \%$ & $19.6 \%$ & $47.3 \%$ & $100 \%$ \\
\hline & $\%$ within learning style & $52.2 \%$ & $51.0 \%$ & $44.6 \%$ & $53.4 \%$ & $50.9 \%$ \\
\hline & $\%$ of Total & $8.2 \%$ & $8.6 \%$ & $10.0 \%$ & $24.1 \%$ & $50.9 \%$ \\
\hline \multirow[t]{4}{*}{ Female } & Frequency & 22 & 24 & 36 & 61 & 143 \\
\hline & \%within gender & $15.4 \%$ & $16.7 \%$ & $25.2 \%$ & $42.7 \%$ & $100 \%$ \\
\hline & \%within learning style & $47.8 \%$ & $49.0 \%$ & $55.4 \%$ & $46.6 \%$ & $49.1 \%$ \\
\hline & $\%$ of Total & $7.6 \%$ & $8.2 \%$ & $12.4 \%$ & $21.0 \%$ & $49.1 \%$ \\
\hline
\end{tabular}

\subsection{Relationship between Learning Styles and Academic Achievement in Agriculture}

The study also sought to determine the relationship between learning style preference and academic achievement of secondary school agriculture students. Student achievement was measured using a 50-item short answer structured test, which was prepared to measure all the three domains of learning: the psychomotor, Cognitive and affective domains in the five main areas in secondary school agriculture

\section{Volume 6 Issue 7, July 2017} www.ijsr.net 


\section{International Journal of Science and Research (IJSR) \\ ISSN (Online): 2319-7064}

Index Copernicus Value (2015): 78.96 | Impact Factor (2015): 6.391

syllabus. Each item carrying 2 points with a possible score ranged from 0-100. The Kenya National Examination Council format shown in table 8 was used to categorize the participants as low, Average, High and Very High.

Table 3: Kenya National Examination Council Performance Rating in Agriculture

\begin{tabular}{|c|c|c|}
\hline $\begin{array}{c}\text { Performance } \\
(\% \text { marks scored })\end{array}$ & Grade distribution & Rating \\
\hline $75-100$ & B+(Plus)-A(Plain) & Very High \\
\hline $60-74$ & B-(Minus) - B (Plain) & High \\
\hline $40-59$ & C-(Minus) -C+(Plus) & Average \\
\hline $01-39$ & E -D+(Plus) & Low \\
\hline \multicolumn{2}{|c}{ Source KNEC KCSE Certificate 2015 }
\end{tabular}

The students' achievement in the Agriculture assessment test in the specified secondary agriculture topics was as shown in Table 4

Table 4: Level of Achievement of Secondary School Agriculture Students

\begin{tabular}{|c|c|c|c|}
\hline Level of achievement & Score range & Frequency & Percent \\
\hline Low & Jan-39 & 121 & 41.6 \\
\hline Average & $40-59$ & 85 & 29.2 \\
\hline High & $60-74$ & 58 & 19.9 \\
\hline Very High & $75-100$ & 27 & 9.3 \\
\hline
\end{tabular}

Total 291 100

Majority of the students, 41.6 percent (121) of the students were low performers whereas 29.2 percent $(85)$ were average performers. It is also revealed that 19.9 percent (58) of the students were high performers and only 9.3 percent (27) were very high in the test administered. This implies that majority (70.8 percent) of the respondents who scored between 01 and 59 percent in the Agriculture Assessment Test were average and low performers. There was need to establish the relationship between learning styles and academic achievement of the students in secondary school Agriculture. The responses are presented in Table 10.

Majority of the students, 41.6 percent (121) of the students were low performers whereas 29.2 percent (85) were average performers. It is also revealed that 19.9 percent (58) of the students were high performers and only 9.3 percent (27) were very high in the test administered. This implies that majority (70.8 percent) of the respondents who scored between 01 and 59 percent in the Agriculture Assessment Test were average and low performers. There was need to establish the relationship between learning styles and academic achievement of the students in secondary school Agriculture. The responses are presented in Table 5.

Table 5: Learning Styles and Academic Achievement of Agriculture Students

\begin{tabular}{|c|c|c|c|c|c|c|}
\hline \multicolumn{6}{|c|}{ Performance } & \multirow[t]{2}{*}{ Total } \\
\hline & & Low & Average & Good & very good & \\
\hline \multirow[t]{4}{*}{ Accommodator } & Count & 18 & 6 & 17 & 5 & 46 \\
\hline & $\%$ within learning style & $39.1 \%$ & $13.0 \%$ & $37.0 \%$ & $10.9 \%$ & $100.0 \%$ \\
\hline & $\%$ within performance & $14.9 \%$ & $7.1 \%$ & $29.3 \%$ & $18.5 \%$ & $15.8 \%$ \\
\hline & $\%$ of Total & $6.2 \%$ & $2.1 \%$ & $5.8 \%$ & $1.7 \%$ & $15.8 \%$ \\
\hline \multirow[t]{4}{*}{ Diverger } & Count & 25 & 12 & 9 & 3 & 49 \\
\hline & $\%$ within learning style & $51.0 \%$ & $24.5 \%$ & $18.4 \%$ & $6.1 \%$ & $100.0 \%$ \\
\hline & $\%$ within performance & $20.7 \%$ & $14.1 \%$ & $15.5 \%$ & $11.1 \%$ & $16.8 \%$ \\
\hline & $\%$ of Total & $8.6 \%$ & $4.1 \%$ & $3.1 \%$ & $1.0 \%$ & $16.8 \%$ \\
\hline \multirow[t]{4}{*}{ Assimilator } & Count & 28 & 20 & 9 & 8 & 65 \\
\hline & $\%$ within learning style & $43.1 \%$ & $30.8 \%$ & $13.8 \%$ & $12.3 \%$ & $100.0 \%$ \\
\hline & $\%$ within performance & $23.1 \%$ & $23.5 \%$ & $15.5 \%$ & $29.6 \%$ & $22.3 \%$ \\
\hline & $\%$ of Total & $9.6 \%$ & $6.9 \%$ & $3.1 \%$ & $2.7 \%$ & $22.3 \%$ \\
\hline \multirow[t]{4}{*}{ Converger } & Count & 50 & 47 & 23 & 11 & 131 \\
\hline & $\%$ within learning style & $38.2 \%$ & $35.9 \%$ & $17.6 \%$ & $8.4 \%$ & $100.0 \%$ \\
\hline & $\%$ within performance & $41.3 \%$ & $55.3 \%$ & $39.7 \%$ & $40.7 \%$ & $45.0 \%$ \\
\hline & $\%$ of Total & $17.2 \%$ & $16.2 \%$ & $7.9 \%$ & $3.8 \%$ & $45.0 \%$ \\
\hline \multirow[t]{4}{*}{ Count } & & 121 & 85 & 58 & 27 & 291 \\
\hline & $\%$ within learning style & $41.6 \%$ & $29.2 \%$ & $19.9 \%$ & $9.3 \%$ & $100.0 \%$ \\
\hline & $\%$ within performance & $100.0 \%$ & $100.0 \%$ & $100.0 \%$ & $100.0 \%$ & $100.0 \%$ \\
\hline & $\%$ of Total & $41.6 \%$ & $29.2 \%$ & $19.9 \%$ & $9.3 \%$ & 100.0 \\
\hline
\end{tabular}

Findings in Table 5 indicate that majority (17.2 percent) of the low achievers adopted converging learning style, while 9.6 percent (28) of the low achievers adopted assimilating learning style. Further, 8.6percent (25) of the low achievers were using diverging learning style. Only 6.2 percent (18) of the low achievers adopted accommodating learning style. Most of the average achievers used accommodating learning style. It should be noted that most of the low achievers used converging learning style $(17.2 \%)$ followed by assimilating learning style.

\subsection{Learning Styles and Achievement in Agriculture Based on Gender}

The study sought to determine the differences in the effect of learning styles on achievement in secondary school agriculture based on gender. The results for analysis using the statistical package for social science showing the means and standard deviation are presented in Table 6. 


\section{International Journal of Science and Research (IJSR) \\ ISSN (Online): 2319-7064}

Index Copernicus Value (2015): 78.96 | Impact Factor (2015): 6.391

Table 6: Descriptive Statistics on Learning Styles, Gender and Achievement

\begin{tabular}{|c|c|c|c|c|}
\hline Learning Style & Gender & Mean & S.D. & $N$ \\
\hline \multirow{3}{*}{ Accommodator } & Male & 2.3750 & 1.17260 & 24 \\
\cline { 2 - 5 } & Female & 2.0000 & 0.97590 & 22 \\
\cline { 2 - 5 } Diverger & Total & $\mathbf{2 . 1 9 5 7}$ & $\mathbf{1 . 0 8 7 7 0}$ & $\mathbf{4 6}$ \\
\hline & Male & 1.8400 & 0.98658 & 25 \\
\cline { 2 - 5 } & Female & 1.7500 & 0.94409 & 24 \\
\cline { 2 - 5 } Assimilator & Total & $\mathbf{1 . 7 9 5 9}$ & $\mathbf{0 . 9 5 6 9 8}$ & $\mathbf{4 9}$ \\
\hline \multirow{3}{*}{ Converger } & Male & 2.0690 & 1.13172 & 29 \\
\cline { 2 - 5 } & Female & 1.8611 & 0.96074 & 36 \\
\cline { 2 - 5 } & Total & $\mathbf{1 . 9 5 3 8}$ & $\mathbf{1 . 0 3 7 2 9}$ & $\mathbf{6 5}$ \\
\hline & Male & 2.0143 & 1.01429 & 70 \\
\cline { 2 - 5 } & Female & 1.9016 & 0.86996 & 61 \\
\cline { 2 - 5 } Total & Total & $\mathbf{1 . 9 6 1 8}$ & $\mathbf{0 . 9 4 7 9 1}$ & $\mathbf{1 3 1}$ \\
\hline & Male & 2.0541 & 1.06128 & 148 \\
\cline { 2 - 5 } & Female & 1.8811 & 0.91536 & 143 \\
\cline { 2 - 5 } & Total & $\mathbf{1 . 9 6 9 1}$ & $\mathbf{0 . 9 9 4 3 3}$ & $\mathbf{2 9 1}$ \\
\hline
\end{tabular}

Majority of female respondents preferred assimilating learning styles while majority of male students' preferred converging learning style. The result indicated that female and male students perceived learning differently. The findings indicated that accommodating learning style had the highest mean of 2.1957 with standard deviation of 1.088 , followed by converging learning style that had a mean of 1.9618. The third and fourth ranked learning styles were assimilating (mean of 1.9538) and diverging (1.7959) respectively. The means presented in Table 10 are in relation to the academic achievement of the students in Agriculture. In all the four learning styles, the male students are dominating in academic achievement. Different results related to boys and girls learning style are due to their characteristic, skill, aptitude, attitude and learning environment.

Table 7: Chi- Square Results on Learning Style and Students' Achievement

\begin{tabular}{|l|l|l|l|}
\hline & Value & df & Significance \\
\hline & & & \\
\hline Chi-Square & 17.78 & 9 & 0.038 \\
\hline Likelihood Ratio & 17.50 & 9 & 0.041 \\
\hline Linear-by-Linear Association & .493 & 1 & 0.048 \\
\hline
\end{tabular}

From the information in Table 7 , a chi-square value of $17.788, \mathrm{df}=9$ and $\mathrm{p}=0.038$ was obtained. Since $\mathrm{p}<0.05$, the null hypothesis is rejected. This implies that there was a significant relationship between learning style and students' achievement in Secondary School agriculture. This confirms the results presented through descriptive statistics. Post-hoc comparisons support that the mean scores for converging and assimilating groups are significantly higher $t$ diverging and accommodating groups. This result was in accordance with those of some other scholars (Malcom, 2009; Kolb, 1984), as they found that accommodators and divergers were slightly less successful students than convergers and assimilators.

With reference to this it can be concluded that agriculture students in Eldoret East Sub-County are academically rewarded for being more abstract and less concrete. This is consistent with Piaget's theory that students develop abstract thinking during adolescence, possibly as a result of environmental (educational) demands. Meanwhile, there is another possible explanation, that is, greater learning occurs when the teaching style matches the students' learning styles than when they are mismatched (Felder \& Brent, 2005).

Thus, it is possible that teachers in the chosen sample have converging and assimilating teaching style. In other words, the higher academic achievement can be the result of the match between teachers' teaching style and the students' learning styles. It was statistically established that there was a significant relationship between learning style and students' achievement in Secondary School agriculture (chisquare $=17.788, \mathrm{df}=9$ and $\mathrm{p}=0.038$ ).

Table 8: ANOVA test on Learning Styles, Gender and Achievement

\begin{tabular}{|l|l|l|l|}
\hline \multicolumn{1}{|c|}{ Source } & df & F & Sig. \\
\hline Learning Style & 3 & 2.244 & 0.029 \\
\hline Gender & 1 & 3.382 & 0.012 \\
\hline Learning style and Gender & 3 & 1.233 & 0.047 \\
\hline Total & 291 & & \\
\hline
\end{tabular}

The results in Table 8 indicate an ANOVA value of 2.244( $\mathrm{F}=2.244), \mathrm{df}=3$ and $\mathrm{p}=0.029$ for learning style and $\mathrm{F}=3.382, \mathrm{df}=1$ and $\mathrm{p}=0.012$ for gender were obtained. Since $\mathrm{p}<0.05$ for both learning style and gender, there was no statistically significant difference in the students' learning styles and achievement in agriculture based on gender. The null hypothesis was rejected implying that there is a statistically significant difference in the effect of learning styles on achievement in agriculture based on gender. That is, the learning styles adopted by students affects the academic achievement of the students in Agriculture differently in as far as gender of the students is concerned. This implied that males and females were perceived to have direct impact on different learning styles. Researchers have proven that both gender and learning styles have an impact on student's achievement. Sendil, (2009) found that there are significant correlation between students' learning styles and gender. Miller, (1990) also found that learning styles between males and females have direct impact on achievement.

\section{Conclusions}

Based on the findings of the study, the following conclusions were drawn:

1) Secondary agriculture students possess all the four learning styles; accommodating, assimilating Converging and Diverging. Majority of secondary school Agriculture students own converging learning styles

2) Mean scores for converging and assimilating groups are significantly higher than diverging and accommodating groups. Therefore it can be concluded that agriculture students in Eldoret East Sub-County tend to learn best through experimentation and less through reflective observation.

3) The learning styles adopted by agriculture students affect their academic achievements as far as gender is concerned. In all the four learning styles, male students have higher mean scores than females.

\section{Volume 6 Issue 7, July 2017 www.ijsr.net}




\section{International Journal of Science and Research (IJSR) \\ ISSN (Online): 2319-7064}

Index Copernicus Value (2015): 78.96 Impact Factor (2015): 6.391

\section{Recommendations}

The following are the recommendations of this study:

1) For better performances in Agriculture, Agriculture teachers should identify the learning styles of their students and use teaching strategies that complement them. The use of multiple teaching methods will greatly enhance the process of teaching and learning and make it effective and rewarding.

2) Students at risk of poor academic achievement especially the slow learners and under achievers should be identified and direct individual and group counseling approaches should be utilized to help them improve their learning styles.

3) Teachers, curriculum planners and experts should apply the use of equal measure in the method of teaching male and female students in schools.

4) Curriculum planners and experts should plan and organize the curriculum bearing in mind individual differences in learning styles of students.

\section{References}

[1] Adel, M. Lari, H., and Louis.(2003). An Investigation into the Preferred Learning Styles of Accounting, Management, Marketing, and General Business Majors. Teaching \&Learning, Fall 2003, Volume 18, (Number $1)$.

[2] Cezair,j.(2003)., Exploring the Impact Gender May Have on Students 'Learning Styles and Course Achievement in Selected Accounting Courses. Fayetteville State University.

[3] Chamorro, (2008). Personality, intelligence and approaches to Learning as predictors of academic performance Personality and Individual Differences: Cambridge University Press

[4] Chang, Y. (2010). Students' Perceptions of Teaching Styles and Use of Learning Strategies. Retrieved from http://trace.tennessee.edu/utk_gradthes/782 27/7/2014

[5] Claxton, C.S. \& Murell, P.H (1987). Learning Styles; Implications for improving Education Practises . ASHE -ERIC Higher

[6] Felder R \& Brent (2005). Understanding student differences.Journal ofEngineering Education, 94(1), 5772. Retrieved on 13/11/2014 from http://www4ncsu.edu/unity/lockers/users/f/felder/public/ Papers/Understanding Differences.pdf

[7] Felder, R \& Spurling, J, (2005) 'Applications, Reliability, and Validity of the Index of Learning Style International Journal of Engineering Education, 21(1), 103-112

[8] Gor C., Agong, S., Acheng, L., Akuno, W. and Andika, D (2012), the interface between mango value chain analysis and the socioeconomic determinants, African journal of horticulture science. 6(1): 1-16.

[9] Honey, P. (1999). Building on Learning Styles (Appendix 2). IMC Tutors Guide. Retreived March 17, 1999, from http://www.mcb.co.uk/services/coursewa/tutguide/tut010.html
[10]Hsu, C. H. C. (1999). Learning Styles of Hospitality Students: Nature or Nurture? Hospitality Management, $18,17-30$

[11] Kolb, D. A. (1984). Experiential learning: Experience as the source of learning and development. Englewood Cliffs, NJ: Prentice-Hall, Inc.

[12] Kolb, D. A. (1985).Experiential learning: Experience as the source of learning and development. Upper Saddle River, NJ: Prentice Hall.

[13] Kolb, A., \& Kolb, D. A. (2009). The learning way: Meta-cognitive aspects of experiential learning. Boston: Hay Group Inc.Kombo, K. D. \& Tromp, A. L. D (2006).Proposal and Thesis Writing: An introduction, Nairobi: Pauline Publications Africa

[14] Kirton, M. J. (2003). Adaption-Innovation: In the context of diversity and change. New York, NY: Routledge.

[15] Kolb, D. A. (2007). Kolb learning style inventory. Experience Based Learning Systems, Inc.

[16]Lamm, A. J., Rhoades, E., Snyder, L., Irani, T., Roberts, T. G., \& Brendemuhl, J. (2011). Utilizing natural cognitive tendencies to enhance agricultural education programs. Journal of Agricultural Education, 52(2). doi: 10.5032/jae.2011.02012

[17] Malcom, M. (2009). The Relationship between Learning Styles and Success in Online Learning. Prescott Valley:Arizona.

[18] Matthews, D.B. (1991). The effects of learning style on grades of first-year college students. Journal of Research in Higher Education, 32(3), 253-267

[19] Marshall. (1999) Understanding student learning. Development of practice.

[20] Miller, D., Finley, J., \& McKinley, D. (1990). Learning approaches and motives: male and female differences and implications for learning assistance programs. Journal of College Student Development, 31, 147-154.

[21] Ornestein, A.C.,(1992). Secondary and middle school teaching methods. , Boston: Harper Collins Publishers.

[22] Roberts, J. W. (2012). Beyond learning by doing: Theoretical currents in experiential education. New York, NY: Routledge.

[23] Sendil, C. (2009). The effects of science student teachers' academic achievements, their grade levels, gender andtype of education they are exposed on their Kolb's learning styles (case of Mugla University, Turkey).Procedia Social and Behavioral Sciences, 1, 1853-1857 